\title{
Klasyfikacje i zadania terenów zieleni we współczesnym mieście
}

\section{Maciej Kłopotowski}

\author{
Politechnika Białostocka, Wydział Budownictwa i Inżynierii Środowiska \\ Katedra Ochrony i Kształtowania Środowiska, Zespót Dydaktyczny Architektury Krajobrazu
}

\begin{abstract}
Streszczenie: Część drugą badań nad klasyfikacją terenów zieleni w mieście poświęcono zdefiniowaniu cech i zadań wyodrębnionych obiektów architektury krajobrazu. Cechy charakteryzujące poszczególne obiekty zdefiniowano w podziale na zagadnienia z zakresu: dostępności terenu, jego funkcji użytkowej oraz sposobu jego urządzenia. Realizowane przez nie zadania określono na podstawie współczesnej teorii z tego zakresu. W podsumowaniu przedstawiono sumaryczne wyniki prowadzonych badań.
\end{abstract}

Słowa kluczowe: architektura krajobrazu, planowanie przestrzenne, tereny zieleni w mieście, zieleń miejska, obiekt architektury krajobrazu

\section{Uwaga metodyczna}

Niniejsza publikacja Tereny zieleni we wspótczesnym mieście. Część 2. Klasyfikacja i zadania terenów zieleni we wspótczesnym mieście stanowi kontynuację części 1. Systematyka obiektów architektury krajobrazu we wspótczesnym mieście. W obu częściach zachowano ciągłość numeracji przypisów, tabel i grafów. Podsumowanie prezentowanych w nich badań oraz spis literatury zamieszczono części drugiego.

Zamieszczone w niniejszej publikacji badania zostały zrealizowane w ramach pracy nr S/WBilŚ/2/2016 i sfinansowane ze środków na naukę MNiSW.

\section{Wstęp}

W podjętych pracach badawczych z zakresu systematyki terenów zieleni w mieście określono ich powiązania z obszarem legislacji z zakresu planowania przestrzennego oraz obiektami architektury krajobrazu zdefiniowanymi. W teorii określono również zdefiniowane strefy funkcjonalne, w których poszczególne z obiekty są lokalizowane.

Drugi etap prac badawczych poświęcono klasyfikacji terenów zieleni w mieście. W wyniku przeprowadzonych analiz, którymi objęto zagadnienia z zakresu wiedzy teoretycznej oraz nomenklatury stosowanej w praktyce projektowej i planistycznej stwierdzono, iż nie ma możliwości wprowadzenia jednej spójnej klasyfikacji. Możliwe jest natomiast prowadzenie trzech równoległych, całkowicie niezależnych podziałów (Ryc. 1.). Za ich podstawę przyjęto: dostępność terenu związaną z jego własnością i wydzieleniem przestrzennym, funkcję użytkową związaną z przeznaczeniem (wykorzystaniem) funkcjonalnym terenu oraz sposób urządzenia i wyposażenia terenu. W przypadku każdej z nich określono cechy, które następnie przyporządkowano konkretnym obiektom architektury krajobrazu. 


\begin{tabular}{|c|c|c|}
\hline \multicolumn{3}{|c|}{ KLASYFIKACJE TERENÓW ZIELENI W MIEŚCIE ZE WZGLĘDU NA } \\
\hline dostępność terenu & funkcja użytkowa & sposób urządzenia \\
\hline
\end{tabular}

Ryc. 1. Klasyfikacje terenów zieleni w mieście (opracowanie autora)

\section{Klasyfikacja terenów zieleni w mieście ze względu na dostępność terenu}

Klasyfikacja terenów zieleni w mieście ze względu na ich dostępność jest bezpośrednio związana z własnością terenu oraz jego udostępnieniem przez właściciela, wielokrotnie związana jest również ze specyficzną funkcją, która jest na nim realizowana. Wprowadzony podział wyróżnia tereny o dostępności: pełnej (nieograniczonej, odpowiadającej pojęciu przestrzeni publicznej), ograniczonej (związanej ze sposobem użytkowania terenu) oraz tereny bez dostępu powszechnego (wydzielone przestrzennie) bądź udostępniane za zgodą ich właściciela (zarządcy) (Ryc. 2.).

\begin{tabular}{|c|c|c|}
\hline \multicolumn{3}{|c|}{ KLASYFIKACJE TERENÓW ZIELENI W MIEŚCIE ZE WZGLĘDU NA DOSTĘPNOŚĆ TERENU } \\
\hline dostępność pełna & dostępność ograniczona & $\begin{array}{l}\text { brak dostępu lub dostęp za zgodą } \\
\text { właściciela }\end{array}$ \\
\hline
\end{tabular}

Ryc. 2. Klasyfikacja terenów zieleni w mieście ze względu na dostępność terenu (opracowanie autora)

Tereny zieleni o pełnej dostępności to przestrzenie publiczne stanowiące własność komunalną. Zgodnie z zapisami ustawy o planowaniu i zagospodarowaniu przestrzennym ${ }^{1}$ są to tereny o szczególnych walorach funkcjonalno - przestrzennych a ich lokalizacja i sposób urządzenia sprzyja nawiązywaniu kontaktów społecznych. Ponadto ich organizacja przestrzenna gwarantuje powszechną dostępność i nie prowadzi do wykluczenia kogokolwiek z jej użytkowania. Zagadnienie wykluczenia odnosi się tu zarówno do sfery ekonomicznej jak i dostępności dla różnych grup użytkowników będących osobami niepełnosprawnymi. W grupie obiektów architektury krajobrazu pełniących na terenie miasta wyżej wymienione role znajdują się zarówno publiczne parki i place jak również dostępne przestrzenie terenów towarzyszących budynkom użyteczności publicznej, tereny otwarte czy leśne. W środowisku mieszkaniowym są to osiedlowe parki i ogrody a przestrzenie te nazywane są społecznymi. Przestrzenie międzyblokowe na terenie osiedli określane są mianem przestrzeni półpublicznych (półspołecznych) co ma im nadawać wydzielony (bez wygrodzeń fizycznych) charakter i umożliwiać ograniczonemu gronu mieszkańców utożsamianie i identyfikowanie się z tą przestrzenią. Tak więc powinna być ona odpowiednio zindywidualizowana w odróżnieniu do częstokroć zunifikowanej przestrzeni publicznej, wyposażanej w aktualnie modne wzorniczo miejskie meble i roślinność (obecnie najczęściej byliny i trawy).

Zagadnienie ograniczonej dostępność terenów zieleni w mieście dotyczy wielu obiektów architektury krajobrazu a przyczyny ograniczenia dostępu mają bardzo zróżnicowane podłoże. Podstawowym z nich jest zabezpieczenie obiektu jak ma to miejsce w przypadku: skwerów miejskich, ogrodów historycznych czy specjalistycznych. Zazwyczaj konkretne obiekty są dostępne bezpłatnie. Ich wygrodzenie ma pełnić rolę ochronną i zamykane są wyłącznie na noc. Ograniczenie dostępu dotyczy również obiektów oświatowo - wychowawczych i opieki zdrowia, gdzie jego zadaniem jest bezpieczeństwo dzieci i osób korzystających z tych placówek.

Całkowite wydzielenie przestrzenne powodujące brak dostępu do konkretnych obiektów architektury krajobrazu dotyczy przede wszystkim współcześnie realizowanego środowiska mieszkaniowego i związane jest z osiedlami strzeżonymi. Dostęp za zgodą właściciela lub zarządcy terenu dotyczy również obiektów prywatnych (jak ogrody działkowe) lub obiektów użyteczności publicznej o specjalnym przeznaczeniu na przykład: terenów na których zlokalizowane są budynki administracyjne lub wojskowe (itp.). Z uwagi na bezpieczeństwo 
użytkowników do terenów tego rodzaju obecnie należy zaliczyć otoczenia obiektów sportowych (szczególnie stadionów i boisk piłkarskich), gdzie selekcja osób wchodzących prowadzona jest w odpowiednim dystansie przestrzennym od obiektu. Działania takie coraz częściej dotyczą obiektów związanych z transportem, w szczególności takich jak lotniska i dworce kolejowe, a wynikają z zagrożenia terrorystycznego.

\section{Klasyfikacja terenów zieleni w mieście ze względu na pełnione funkcje użytkowe}

Klasyfikacja terenów zieleni w mieście ze względu na pełnione przez nie funkcje użytkowe prowadzi do zdefiniowania ich jednoznacznego przeznaczenia. Analizy podziałów istniejących w teorii pozwalają wyodrębnić tereny przeznaczone do: rozdzielania struktur zwartych miasta, izolowania przestrzennego obiektów i infrastruktury stanowiącej uciążliwość, szeroko pojętej rekreacji, wypoczynku, sportu i turystyki na terenach miejskich oraz tereny związane otoczeniem budynków publicznych i ponadto tereny związane z produkcją rolniczą (niegdyś określane mianem terenów żywicielskich) oraz inne, nie mieszczące się w zaprezentowanym podziale, skupiające takie obiekty jak: cmentarze, tereny łąk i nieużytków oraz tereny zalewowe nie wykorzystywane turystycznie i gospodarczo (Ryc. 3.).

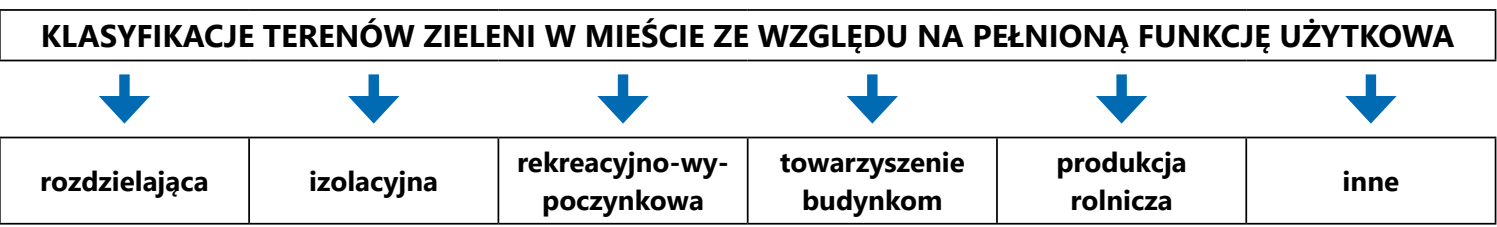

Ryc. 3. Klasyfikacja terenów zieleni w mieście ze względu na pełnione funkcje użytkowe (opracowanie autora)

Tereny zieleni rozdzielającej to bufory przestrzenne pomiędzy poszczególnymi zespołami mieszkaniowymi (osiedlami i dzielnicami) realizowane na terenach miast od połowy wieku dwudziestego i stanowiące jeden z rezultatów wdrożenia w praktyce zasad Karty Ateńskiej. W wielu sytuacjach jest to zieleń naturalna, zastana w urbanizowanej przestrzeni (dawne lasy lub pola uprawne dziś pozbawione funkcji gospodarczej), adoptowana na potrzeby współczesnej rekreacyjni. Częstokroć jako zieleń rozdzielająca wykorzystywane są miejskie tereny otwarte stanowiące łąki oraz obszary podmokłe i obniżone (z zastoinami mgieł), które nie mogą zostać wykorzystane pod zabudowę mieszkaniową (lub inną np.: handlową, przemysłową). Przestrzenie te zwykle (zgodnie z modernistycznymi założeniami) bywają niezagospodarowane lub stopień ich urządzenia jest bardzo niski, a ich użytkowanie związane jest z turystyką pieszą i rowerową, rzadziej grami zespołowymi. Częstym sposobem wykorzystania tych terenów w strukturze miejskiej jest lokowanie na nich ogrodów działkowych. Ich układ w przestrzeni miasta stanowi istotne ogniwo miejskiego systemu przyrodniczego. W teorii utożsamiany jest on z rozwojem historycznych układów promienistych oraz pierścieniowo - promienistych ${ }^{2}$.

Tereny zieleni o funkcji izolacyjnej w przestrzeniach miast występują w dwóch rodzajach. Po pierwsze jako izostrefa obiektów uciążliwych przestrzennie takich jak: zakłady przemysłowe (realizacje $z$ lat pięćdziesiątych i sześćdziesiątych dwudziestego wieku, które związane są z niwelacją zanieczyszczania środowiska przez zakłady przemysłu ciężkiego) oraz wysypiska i spalarnie śmieci a także elektrociepłownie. Współcześnie funkcje takie nadawane są głównie terenom przyległym do obiektów komunikacyjnych a wśród nich: lotnisk i torowisk kolejowych oraz dróg ekspresowych, które to z uwagi na swą specyfikę funkcjonalną sytuowane są z dala od stref zamieszkania i usług publicznych. Po drugie zieleń izolacyjna zlokalizowana w przestrzeniach zurbanizowanych, którą stanowi zieleń przyuliczna towarzysząca ciągom pasów drogowych. Realizowana jest ona przy dużych miejskich arteriach komunikacyjnych i ma za zadanie ochronę budynków mieszkalnych i usługowych przed hałasem i zanieczyszczeniem spalinami. Zwykle sprowadzona jest ona do nasadzeń szpalerów drzew w sąsiedztwie skrajni pasów drogowych oraz krzewów w pasach rozdzielających pasma jezdni. Pasy krzewów są stosowane również do oddzielania chodników, ścieżek rowerowych i jezdni. Korzysta się przy tym z roślin odpornych na trudne warunki środowiskowe w tym zasolenie. Rośliny te podlegają stałemu monitoringowi 
i ocenie stanu ich zdrowotności. Na obszarach ściśle zurbanizowanych w okresach około dziesięcioletnich przeprowadza się ich wymianę. W grupie tej zieleni klasyfikowane są również pasy trawnikowe w torowiskach tramwajowych oraz zieleń w przestrzeni pomiędzy wielorodzinnymi budynkami mieszkalnymi i ulicami (zielona otulina zabudowy mieszkaniowej). Zaleca się by pasy te wynosiły $10-15 \mathrm{~m}$, dzięki czemu zyskują one charakter zieleńców, które to jednak ze względu na sytuowanie i sposób zagospodarowania (częstokroć brak siedzisk) nie posiadają funkcji rekreacyjnej.

Tereny zieleni rekreacyjno-wypoczynkowej są podstawą terenów zielonych na obszarach zabudowy mieszkaniowej i śródmiejskiej. Powstały w wyniku adaptacji na potrzeby społeczne dawnych parków i ogrodów prywatnych i klasztornych lub zakładano je jako nowe - głównie na terenach współczesnych realizacjach mieszkaniowych. W zależności od lokalizacji parki te są dzielone na: centralne, dzielnicowe i osiedlowe oraz realizowane od lat trzydziestych parki ludowe - duże powierzchniowo, o bardzo bogatym programie funkcjonalnym. Uzupełniają je obiekty takie jak: zieleńce, skwery oraz bulwary i promenady. Obiekty te, z uwagi na swe rozproszenie przestrzenne, zwykle nie tworzą jednorodnego układu przestrzennego i określane są mianem systemu plamowego $^{3}$. W swym wyposażeniu są nasycone starannie zaprojektowanymi przestrzeniami oraz elementami małej architektury. Wielkości tych obiektów od początku lat pięćdziesiątych, do połowy lat osiemdziesiątych były sparametryzowane. W grupie tej klasyfikowane są również tereny parków i ogrodów historycznych oraz specjalistycznych (sprofilowanych zadaniowo takich jak ogrody zoologiczne czy parki dydaktyczne), ponadto tereny związane z czynnym uprawianiem sportu i turystyki na terenach miejskich oraz otoczenie obiektów pełniących funkcje sportowe.

Tereny związane z budynkami, zwłaszcza lokalizowanymi na wydzielonych działkach, pełnią określone i preryjnie zdefiniowane funkcje użytkowe. W zależności od funkcji budynku stanowią ich dopełnienie funkcjonalne (jak ma to miejsce w przypadku placówek oświatowo - wychowawczych takich jak: szkoły, przedszkola, żłobki), terapeutyczne (jak ma to miejsce w przypadku obiektów ochrony zdrowia i opieki społecznej). Stanowią również ich wyposażenie uzupełniające (dopełniające, podkreślające) formę architektoniczną obiektu (jak ma to miejsce w przypadki obiektów sakralnych oraz obiektów kultury i sztuki a także budynków biurowych i handlowych). W przypadku wszystkich z przytoczonych tu sytuacji tereny te projektowane są z niezwykłą pieczołowitością w oparciu o odrębne zasady a celem działań inwestorów je realizujących jest budowanie poprzez zieleń dobrego wizerunku firmy lub instytucji.

Tereny związane z produkcją rolniczą zwykle są pozostałościami dawnych gospodarstw rolnych (częstokroć w okresie po Il wojnie światowej upaństwowionych), związanych z sadownictwem lub ogrodnictwem rzadziej uprawą zbóż. Do grupy tej można zakwalifikować tereny ogrodów działkowych, choć ich właściciele coraz częściej ograniczają zakres uprawy warzyw na rzecz roślin ozdobnych lub wręcz wykorzystywania terenu działki wyłącznie do celów rekreacyjnych.

W grupie terenów określonych mianem inne sklasyfikowano poza nieużytkami miejskimi tereny cmentarzy, które nie wpisują w żadną z powyższych grup. Ich odrębność podkreśla również indywidualne traktowania w polskiej legislacji.

\section{Klasyfikacja terenów zieleni w mieście ze względu na sposób urządzenia i wyposażenia terenu}

Klasyfikacja terenów zieleni w mieście ze względu na sposób ich urządzenia i wyposażenia wiąże się z zagadnieniami estetycznymi i dotyczy sfery ich projektowania, realizacji i utrzymania. Z uwagi na te aspekty tereny zieleni w mieście podzielono na: projektowane i realizowane kompleksowo, realizowane z udziałem społecznym (polegającym na współprojektowaniu, udziale w wykonawstwie, współodpowiedzialności za użytkowanie) oraz takie które zagospodarowane zostały w wyniku samowoli inwestycyjnej ich wykonawców (zwykle roszczących sobie do nich prawo lub chcących poprzez takie działania zaistnieć społecznie). Ponadto wyodrębniono tereny pozostawione bez zagospodarowania (z bardzo ograniczoną ingerencją człowieka w ich urządzenie) (Ryc. 4.). 


\section{KLASYFIKACJE TERENÓW ZIELENI W MIEŚCIE ZE WZGLĘDU NA URZĄDZENIE I WYPOSAŻENIE TERENU}

\begin{tabular}{|c|c|c|c|}
\hline $\begin{array}{c}\text { tereny projektowane } \\
\text { i realizowane } \\
\text { kompleksowo }\end{array}$ & $\begin{array}{c}\text { tereny powstające przy } \\
\text { współudziale społecznym }\end{array}$ & $\begin{array}{c}\text { tereny zagospodarowane } \\
\text { w wyniku samowoli } \\
\text { inwestycyjnej }\end{array}$ & $\begin{array}{c}\text { tereny pozostawione bez } \\
\text { zagospodarowania }\end{array}$ \\
\hline
\end{tabular}

Ryc. 4. Klasyfikacja terenów zieleni w mieście ze względu na sposób urządzenia i wyposażenia terenu (opracowanie autora)

Tereny projektowane i realizowane kompleksowo to przede wszystkim obiekty prestiżowe w skali miasta lub takie, które mają się stać wizytówką ich właścicieli (na przykład otoczenie obiektów sakralnych). Poza zleceniami publicznymi związanymi z obiektami użyteczności publicznej oraz zagospodarowaniem przestrzeni publicznych w mieście dotyczą one realizacji miejskich (gminnych), które w ramach jednej inwestycji wymagają zagospodarowania terenu związanego z budynkiem. W szczególności dotyczy to placówek oświatowo - wychowawczych. Realizacje te powstają w wyniku świadomego w pełni kontrolowanego procesu, który prowadzony jest przez odpowiednio, zawodowo przygotowane osoby. Częstokroć konkretne obiekty są realizowane na podstawie prac nagrodzonych w konkursach architektonicznych, które stanowią gwarancję ich jakości użytkowej i estetycznej.

Tereny zagospodarowywany przy współudziale społecznym realizowane są obecnie w wyniku działań nazywanych partycypacją i odbywa sią na wielu etapach: od projektu, poprzez wykonawstwo (niegdyś nazywane czynem społecznym) do użytkowania. Działania związane z udziałem społecznym przy realizacji obiektów architektury krajobrazu mają w Polsce tradycję sięgającą lat czterdziestych ubiegłego wieku. Wówczas to dotyczyły one budowy parków ludowych (miejskich i osiedlowych). Prace wykonywane przez "fachowców" na terenie tych obiektów ograniczały się do przygotowaniu terenu (prac ziemnych związanych z jego kształtowaniem) oraz wytyczeniu i budowie nawierzchni i instalacji oświetleniowej. Pozostałe prace ogrodnicze i wykończeniowe realizowano w tak zwanych czynach społecznych przy zaangażowaniu mieszkańców lub pracowników zakładów pracy. Powstające w tym czasie realizacje związane z mieszkalnictwem niemalże w całości spoczywały na barkach społecznych. Pod koniec lat siedemdziesiątych dwudziestego wieku aktywność społeczna realizowana w formie czynów uległa całkowitemu skompromitowaniu. Przyczyną tego stał się fakt, iż czyn społeczny stał się swoistą osobliwością i narzędziem propagandowym PRL-owskich władz a udział w nim wymuszoną koniecznością. Współcześnie działania inwestycyjne z udziałem społecznym należy podzielić na trzy etapy: projektowy, wykonawczy i eksploatacyjny. Pierwszy polega na badaniu preferencji przyszłych użytkowników oraz zaproszeniu ich do czynnej kreacji projektowej. Drugi na udziale w realizacji, którą dziś określa się mianem aktywności społecznej. Kolejny etap to społeczna kontrola nad obiektem, która polega na wspólnym dbaniu o wyposażenie i szatę roślinną.

Samowola inwestycyjna w zakresie zagospodarowania przestrzeni miejskich z przeznaczeniem na obiekty architektury krajobrazu dotyczy wyłącznie terenów mieszkaniowych. Związana jest ona z realizacją przedogródków przy wejściach do klatek schodowych oraz klombów ozdobnych w przestrzeniach międzyblokowych i rzadziej publicznych. Realizacje te są zieloną odpowiedzią ich autorów - „właścicieli", na potrzebę zaznaczenia własnego terytorium oraz indywidualizację („oswojeniem”) anonimowej przestrzeni. Działania tak że poza realizacją rabat bylinowych polegają na opiekowaniu się wybranym istniejącym drzewem lub sadzeniem własnego (zwykle ozdobnego drzewa lub krzewu). Odrębne zagadnienie stanowi tak zwana „partyzantka ogrodnicza" sprowadzająca się do zakładania w przestrzeni miejskiej ogrodu warzywnego o cechach użytkowych. Jego właściciele nie kierują się względami estetycznymi lecz promują nową filozofię funkcjonowania przestrzeni miejskich. Odwołują się w niej do pojęć z zakresu zrównoważonego rozwoju i racjonalnego gospodarowania. W odniesieniu do polskich tradycji nawiązują oni do działań z połowy lat osiemdziesiątych dwudziestego wieku, kiedy to większość budynków wielorodzinnych została otoczona tego rodzaju ogrodami. Wówczas działania te miały podłoże ekonomiczne i stanowiły wyraz zaradności społeczny będącej odpowiedzią na niedobory kryzysu gospodarczego.

Tereny pozostawione bez zagospodarowania to obszary trudne inwestycyjnie z uwagi na ich uwarunkowania lokalizacyjne lub przyrodnicze. Zazwyczaj są to tereny zalewowe rzek oraz tereny podmokłe, w grupie tej klasyfikowane są również miejskie łąki i błonia oraz lasy komunalne. Terenami, na których nie są prowadzone inwestycje pozostają również obszary chronione (rezerwaty przyrodnicze). 


\section{Analiza porównawcza prowadzonych klasyfikacji}

Zestawienie porównawcze wprowadzonych klasyfikacji terenów zieleni w mieście zamieszczono poniżej w Tabeli 2. Zilustrowano w niej wprowadzoną wcześniej systematykę oraz przyporządkowanie poszczególnym terenom (zdefiniowanym w podziale Il stopnia) cechy wynikające z prowadzonych klasyfikacji. Poszczególne z nich oznaczono symbolem „•". W szczególnych przypadkach poszczególnym terenom przyporządkowano dwa ozna-


przynależne do wyżej wymienionych terenu w sposób różnorzędny realizują cechy zdefiniowane w klasyfikacji.

Poniższe zestawienie pozwala na prześledzenie zróżnicowania zdefiniowanych terenów zieleni w mieście. Tym samym pozwala na ich charakterystykę w zakresie wyróżnionych cech, dzięki układowi Tabeli 2. Możliwe jest ich przeniesienie na konkretne obiekty architektury krajobrazu ${ }^{4}$.

Tabela 1. Zestawienie porównawcza terenów zieleni w mieście (podział I i II stopnia) z przyporządkowanymi im cechami zdefiniowanymi w klasyfikacjach prowadzonych ze względu na: funkcję użytkową terenu, dostępność terenu oraz urządzenie i wyposażenie terenu (opracowanie autora).

\begin{tabular}{|c|c|c|c|c|c|c|c|c|c|c|c|c|c|c|c|}
\hline \multirow{6}{*}{ 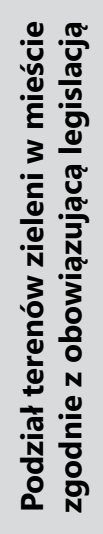 } & \multirow{6}{*}{ 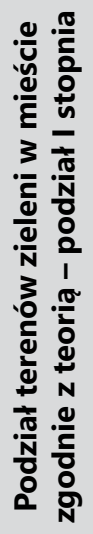 } & \multirow{6}{*}{ 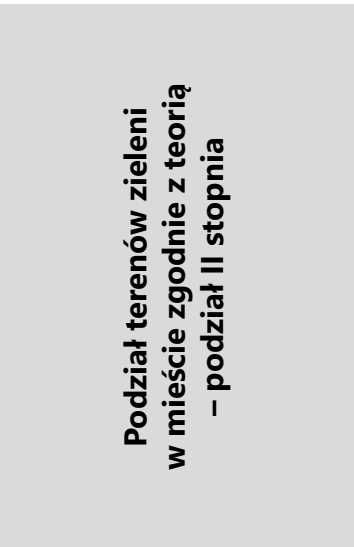 } & \multicolumn{13}{|c|}{ Klasyfikacje ze względu na } \\
\hline & & & \multicolumn{3}{|c|}{$\begin{array}{c}\text { dostępność } \\
\text { terenu }\end{array}$} & \multicolumn{6}{|c|}{ funkcję użytkową terenu } & \multicolumn{4}{|c|}{$\begin{array}{c}\text { urządzenie } \\
\text { i wyposażenie } \\
\text { terenu }\end{array}$} \\
\hline & & & \multicolumn{13}{|c|}{$\begin{array}{l}\text { 1. Dosteepność pełna. 2. Dostępność ograniczona. } \\
\text { 3. Brak dostępu lub dostęp za zgodą właściciela }\end{array}$} \\
\hline & & & \multirow{2}{*}{\multicolumn{13}{|c|}{$\begin{array}{l}\text { 11. Rozdzielająca. 12. Izolacyjna. 13. Rekreacyjno-wypoczynkowa. } \\
\text { 14. Towarzyszenie budynkom. } 15 \text {. Produkcja rolnicza. 16. Inne } \\
\text { 21. Tereny projektowane i realizowane kompleksowo. 22. Tereny } \\
\text { powstające przy współudziale społecznym. 23. Tereny zagospodaro- } \\
\text { wane w wyniku samowoli inwestycyjnej. } 24 \text {. Tereny pozostawione bez } \\
\text { zagospodarowania }\end{array}$}} \\
\hline & & & & & & & & & & & & & & & \\
\hline & & & 1 & 2 & 3 & 11 & 12 & 13 & 14 & 15 & 16 & 21 & 22 & 23 & 24 \\
\hline ZN & $\mathrm{ZN} / 1$ & $\begin{array}{c}\mathrm{ZN} / 1 / 1 \text { - tereny } \\
\text { rezerwatów przyrody na } \\
\text { terenie miast }\end{array}$ & • & & 0 & • & O & $\bullet$ & O & 0 & 0 & 0 & 0 & 0 & $\bullet$ \\
\hline ZL & $\mathrm{ZL} / 1$ & ZL/1/1 - lasy komunalne & $\bullet$ & 0 & O & $\bullet$ & 0 & $\bullet$ & O & 0 & 0 & 0 & 0 & 0 & $\bullet$ \\
\hline \multirow{4}{*}{ ZP } & \multirow[b]{2}{*}{$\mathrm{ZP} / 1$} & $\begin{array}{l}\text { ZP/1/1 - tereny parków } \\
\text { i ogrodów zabytkowych }\end{array}$ & 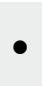 & & O & O & O & $\bullet$ & O & 0 & O & $\bullet$ & O & 0 & 0 \\
\hline & & $\begin{array}{c}\text { ZP/1/2 - tereny } \\
\text { zabytkowych grodzisk } \\
\text { i fortyfikacji }\end{array}$ & 0 & $\bullet$ & 0 & 0 & 0 & $\bullet$ & & 0 & 0 & $\bullet$ & O & 0 & $\mathrm{O}$ \\
\hline & \multirow[b]{2}{*}{$\mathrm{ZP} / 2$} & $\begin{array}{l}\text { ZP/2/1 - tereny } \\
\text { ogrodów botanicznych }\end{array}$ & 0 & $\bullet$ & O & O & O & $\bullet$ & O & O & O & $\bullet$ & O & O & O \\
\hline & & $\begin{array}{l}\text { ZP/2/2 - tereny } \\
\text { ogrodów tematycznych } \\
\text { i dydaktycznych }\end{array}$ & & & & $\bullet$ & & • & & 0 & 0 & & O & 0 & 0 \\
\hline
\end{tabular}

4 Szczegółowa analiza porównawcza prowadzona na zbiorze wszystkich obiektów architektury krajobrazu dała wyniki tożsame z zaprezentowanymi w tekście niniejszego opracowania. Analiza ta potwierdziła trafność wprowadzonych podziałów II stopnia (patrz Tabela 2.) Sytuacje gdy poszczególnym terenom w ramach jednej klasyfikacji przyporządkowano więcej niż jedną cechę dotyczą grup obiektów sklasyfikowanych w ranch jednego terenów wyróżnionego w podziale II stopnia. 


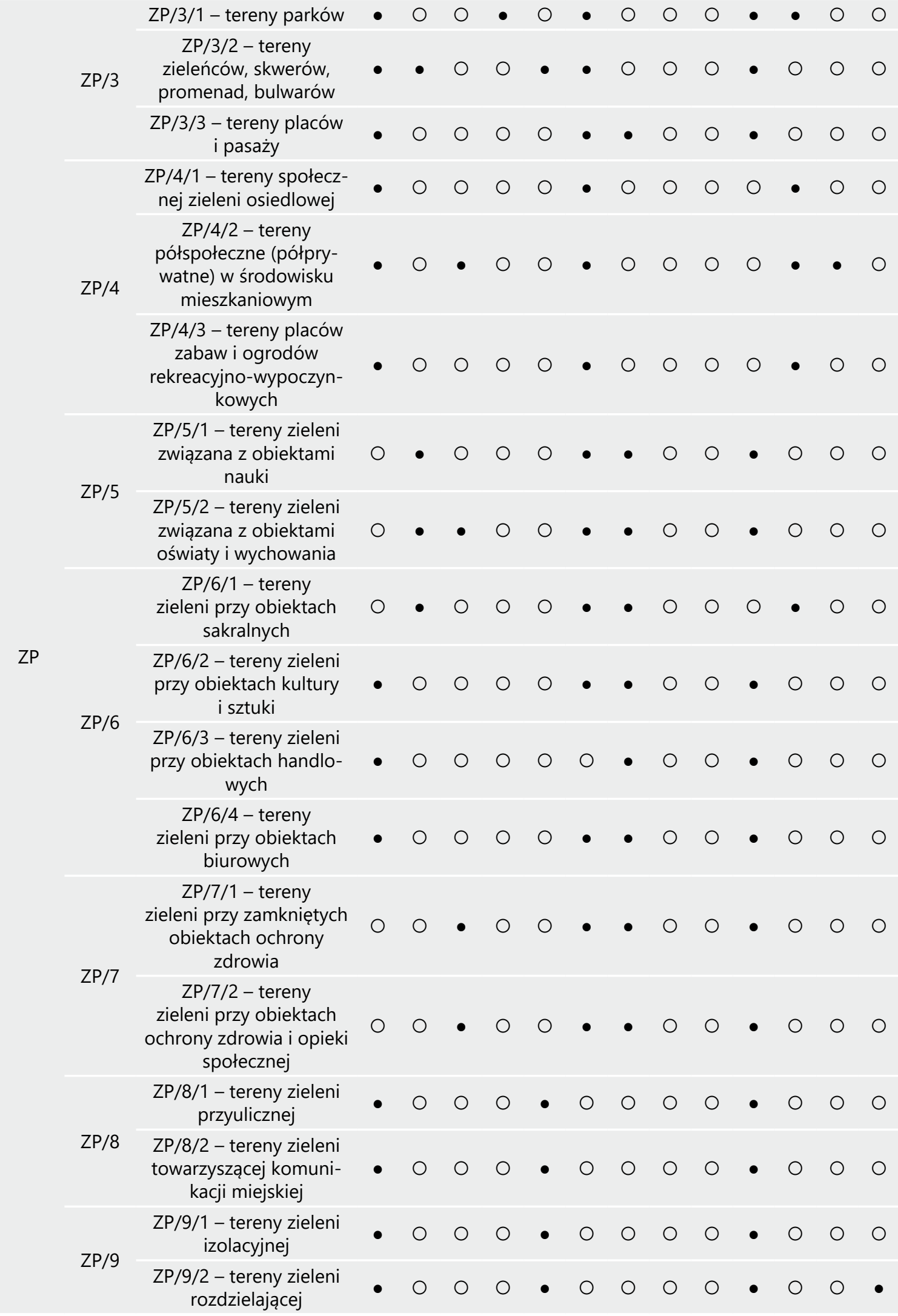




\begin{tabular}{|c|c|c|c|c|c|c|c|c|c|c|c|c|c|c|c|}
\hline ZPR & ZPR/1 & $\begin{array}{c}\text { ZPR/1/1 - tereny } \\
\text { zieleni izolującej zakłady } \\
\text { przemysłowe }\end{array}$ & $\bullet$ & O & • & ○ & $\bullet$ & O & O & 0 & 0 & & 0 & 0 & $\bullet$ \\
\hline \multirow{6}{*}{ ZS } & \multirow{6}{*}{$\mathrm{ZS} / 1$} & $\begin{array}{l}\text { ZS/1/1 - tereny zieleni } \\
\text { przy stadionach i halach } \\
\text { sportowych }\end{array}$ & 0 & ○ & • & $\bullet$ & 0 & $\bullet$ & • & 0 & 0 & - & 0 & 0 & O \\
\hline & & $\begin{array}{l}\text { ZS/1/2 - tereny zieleni } \\
\text { przy zespołach boisk } \\
\text { i obiektach terenowych }\end{array}$ & 0 & $\bullet$ & 0 & O & 0 & $\bullet$ & $\bigcirc$ & 0 & O & $\bullet$ & 0 & 0 & 0 \\
\hline & & $\begin{array}{c}\text { ZS/1/3 - tereny zieleni } \\
\text { przy plażach i kąpieli- } \\
\text { skach }\end{array}$ & O & $\bullet$ & O & O & 0 & $\bullet$ & O & 0 & O & $\bullet$ & O & 0 & 0 \\
\hline & & $\begin{array}{c}\text { ZS/1/4 - tereny zieleni } \\
\text { przy bazach sportów } \\
\text { wodnych }\end{array}$ & 0 & $\bullet$ & O & O & 0 & $\bullet$ & 0 & 0 & 0 & $\bullet$ & O & 0 & 0 \\
\hline & & $\begin{array}{c}\text { ZS/1/5 - tereny zieleni } \\
\text { przy stokach narciar- } \\
\text { skich }\end{array}$ & 0 & $\bullet$ & 0 & O & O & $\bullet$ & 0 & 0 & 0 & $\bullet$ & 0 & 0 & $\mathrm{O}$ \\
\hline & & $\begin{array}{l}\mathrm{ZS} / 1 / 6 \text { - tereny zieleni } \\
\text { przy trasach sportowych }\end{array}$ & P & O & 0 & O & 0 & $\bullet$ & 0 & 0 & 0 & • & 0 & 0 & 0 \\
\hline ZD & ZD/1 & $\begin{array}{c}\text { ZD/1/1 - tereny } \\
\text { ogrodów działkowych }\end{array}$ & 0 & 0 & • & $\bullet$ & 0 & • & 0 & $\bullet$ & 0 & 0 & 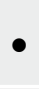 & 0 & 0 \\
\hline ZC & $\mathrm{ZC} / 1$ & $\mathrm{ZC} / 1 / 1$ - cmentarze & 0 & $\bullet$ & O & O & O & O & O & 0 & $\bullet$ & $\bullet$ & 0 & O & 0 \\
\hline ZR & ZR/1 & $\begin{array}{c}\text { ZR/1/1 - tereny zieleni } \\
\text { związane z produkcją } \\
\text { rolną }\end{array}$ & - & 0 & $\bullet$ & 0 & 0 & 0 & 0 & • & & - & 0 & 0 & 0 \\
\hline ZB & ZB/1 & $\begin{array}{l}\text { ZB/1/1 - tereny łąk } \\
\text { i nieużytków }\end{array}$ & 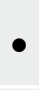 & 0 & O & $\bullet$ & O & 0 & 0 & 0 & $\bullet$ & 0 & 0 & 0 & - \\
\hline ZZ & ZZ/1 & $\begin{array}{c}\text { ZZ/1/1 - tereny } \\
\text { zalewowe o różnym } \\
\text { sposobie użytkowania }\end{array}$ & - & 0 & O & O & ○ & 0 & O & O & $\bullet$ & 0 & 0 & O & - \\
\hline
\end{tabular}

\section{Zadania terenów zieleni w mieście}

W latach pięćdziesiątych miejskim terenom zieleni zdefiniowano ich społeczne zadania. Podzielono je na: biologiczne, usługowe i plastyczne. Pierwsze z nich miały zapewnić kształtowanie odpowiedniego, korzystnego dla człowieka mikroklimatu (regulować wahania temperatur i warunki wilgotnościowe, regulować nasłonecznienie i przewietrzanie) oraz stanowić barierę ochronną przed hałasem i zanieczyszczeniami powietrza. Drugie zapewnić przestrzeń do realizacji wypoczynku czynnego i biernego. Zaś trzecie miały zapewnić mieszkańcom osiedli przebywanie w estetycznym krajobrazie, w którym rośliny będą uzupełniały i podkreślały formy architektoniczne budynków ${ }^{5}$. W kolejnych dekadach zadania spoteczne stawiane terenom zieleni zastąpiono definiowaniem petnionych przez nie funkcji. Wyróżniono wśród nich: zdrowotne i biologiczne, społeczne, estetyczne i gospodarcze. Trzy pierwsze odpowiadają zdefiniowanym powyżej zadaniom, funkcję gospodarczą rozumiano jako żywicielską i siedliskową zwierząt oraz jako osłonę przeciwwietrzną, przeciwerozyjną i przeciwinwersyjną ${ }^{6}$. W latach dziewięćdziesiątych funkcje terenów zieleni w mieście definiowano jako: zdrowotne i biologiczne (odnosząc je do zagadnień związanych z ochroną człowieka przed kurzem, sadzą, wyziewami i zadymieniem, 
Tabela 2. Zestawienie porównawcza terenów zieleni w mieście (podział I i ll stopnia) z z przyporządkowanymi im zadaniami (opracowanie autora).

\section{Podział terenów zieleni w mieście zgodnie z obowiązującą legislacją}

ZN

ZL

\section{Podział terenów zieleni} w mieście zgodnie $\mathbf{z}$ teorią - Podział I stopnia

\section{ZADANIA TERENÓW ZIELENI W MIEŚCIE}

1. biologiczne, 2. zdrowotne, 3. usługowe, 4. społeczne, 5. psychiczne, 6. wychowawcze, 7. dydaktyczne,

8. artystyczne, 9. estetyczne, 10. reprezentacyjne, 11. gospodarcze, 12. ochronne, 13. przeciwpożarowe

$\begin{array}{lllllllllllll}1 & 2 & 3 & 4 & 5 & 6 & 7 & 8 & 9 & 10 & 11 & 12 & 13\end{array}$

ZN/1 - tereny rezerwatów przyrody

$$
\text { ZL/1 - lasy komunalne }
$$

ZP/1 - tereny zieleni będące

obiektami historycznych

ZP/2 - tereny zieleni będące obiektami specjalistycznymi

ZP/3 - tereny zieleni publicznych obiektów miejskich

ZP/4 - tereny zieleni związane z mieszkalnictwem

$\mathrm{ZP} / 5$ - tereny zieleni związane z obiektami nauki, oświaty i wychowania

ZP/6 - tereny zieleni związane z obiektami użyteczności publicznej ZP/7 - tereny zieleni przy obiektach ochrony zdrowia i opieki społecznej

ZP/8 - tereny zieleni związane $z$ komunikacją

ZP/9 - tereny zieleni specjalnego przeznaczenia ZPR/1/1 - tereny zieleni izolującej zakłady przemysłowe

$$
\begin{gathered}
\text { ZS/1 - tereny sportu } \\
\text { i rekreacji } \\
\text { ZD/1 - tereny ogrodów } \\
\text { działkowych }
\end{gathered}
$$

\section{ZD/1 - tereny ogrodów}

$$
\text { ZC/1 - cmentarze }
$$

\section{ZZ/1 - tereny zalewowe}

o różnym sposobie użytkowania

ZR/1 - tereny zieleni związane z produkcją rolną

\section{ZB/1 - tereny łąk} i nieużytków
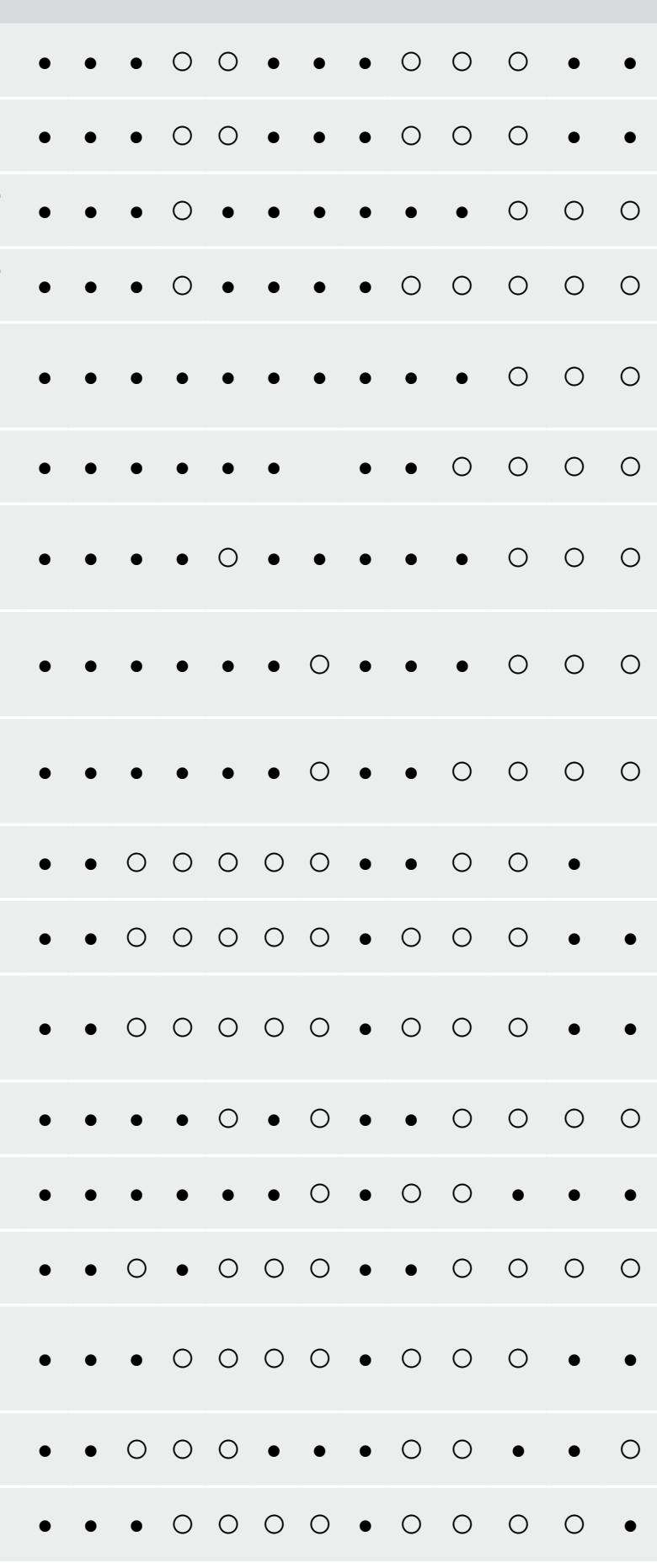
ochroną dzielnic mieszkaniowych przed wiatrem i lotnymi piaskami oraz hałasem); społeczne, psychiczne i wychowawcze (podkreślając, że tereny zieleni w mieście służą wypoczynkowi, rozrywce i odprężeniu psychicznemu po pracy, jednocześnie są miejscem uprawiania sportów i zabaw dziecięcych co owocuje zbliżeniem się człowieka do przyrody, niejednokrotnie są jednocześnie terenami dydaktycznymi); estetyczne, artystyczne i plastyczne (zwracając uwagę na walory estetyczne zieleni zmieniającej się w zależności od pór roku, podkreślając iż elementy zieleni wpływają na kształtowanie krajobrazu miasta oraz wprowadzanie urozmaicenia w jego sylwecie, ponadto tworzenie kontrastu ze sztywną zabudową ulic i dodawanie godności, skali i tła budynkom monumentalnym); ochronne (pełniące rolę osłon szlaków komunikacyjnych i maskowania obiektów wojskowych, co wobec powszechnego dostępu do zdjęć satelitarnych straciło na znaczeniu); przeciwpożarowe (ograniczające rozprzestrzenianie się ognia); żywicielskie i ekonomiczne (wskazując na wykorzystanie produkcyjne terenów rolniczych, ogrodniczych i leśnych) ${ }^{7}$. W wielu publikacjach z zakresu teorii oraz takich, w których prezentowane są obiekty architektury krajobrazu, funkcje społeczne łączone są z ze społecznym użytkowaniem terenu, zaś funkcje estetyczne nie tylko z jego walorami plastycznymi ale również ze sposobem jego zagospodarowania.

Podjęte przez autora prace klasyfikacyjne mają między innymi na celu rozłączenie pojęć funkcji użytkowej terenu (jego przeznaczenia i wykorzystania funkcjonalnego) i pełnionej przez ten teren funkcji (zadania realizowanego przez teren). W celu wprowadzenia jednoznacznego (nie pokrywającego się) nazewnictwa postanowiono powrócić do pojęć historycznych zadania realizowanego przez obiekt (teren) architektury krajobrazu. Definiując zadania posiłkowano się pojęciami znanymi w teorii współczesnej. Na podstawie ich analizy nowe zadania określono jako: biologiczne (związane z funkcjami przyrodniczymi miasta i budową jego systemu przyrodniczego), zdrowotne (związane z tworzeniem mikroklimatu miejsca, w tym regulacji wilgotności i temperatury oraz nasłonecznienia, ponadto hałasu, zapylenia i regulujące ruchu powietrza), usługowe (związane z organizacją miejsca przeznaczonego do rekreacji i uprawiania sportu z uwzględnieniem różnych wiekowo grup użytkowników), społeczne (związane z budową środowiska sprzyjającego nawiązywaniu kontaktów społecznych jednocześnie z budową przestrzeni dostępnej), psychiczne (umożliwiające odpoczynek bierny i poprawę samopoczucia), wychowawcze (związana z rozwojem człowieka w otoczeniu przyrodniczym i przez to nauce poszanowania go), dydaktyczne (związane z poznawaniem świata flory i fauny oraz relacji pomiędzy nimi), artystyczne (związane z walorami plastycznymi roślin w tym ich zmiennością w ciągu roku), estetyczne (związane z wartościami estetycznymi szaty roślinnej i uzupełnianiem przez nią kompozycji architektonicznych i urbanistycznych), reprezentacyjne (związane z budowaniem prestiżowego wizerunku miejsca), gospodarcze (związane z zadaniami żywicielskimi i produkcją rolniczą oraz hodowlą zwierząt), ochronne (związane z tworzeniem barier przestrzennych zabezpieczających przed hałasem, wiatrem i zanieczyszczeniem powietrza), przeciwpożarowe (związane ze spowalnianiem rozprzestrzeniania się ognia).

Wyniki analizy porównawczej miejskich terenów zieleni ze zdefiniowanymi zadaniami realizowanymi przez obiekty architektury krajobrazu pozwalają na doprecyzowanie cech poszczególnych wyodrębnionych obiektów. W Tabeli 4. zaprezentowano podział terenów zieleni w mieście I stopnia ze zdefiniowanymi trzynastoma zadaniami. Badania prowadzone były na grupie wszystkich zdefiniowanych obiektów. Ich wynik potwierdził spójność wyłonionych grup i zgodność zadań we wszystkich obiektach rozpatrywanych w ramach wyżej wymienionego podziału.

\section{Podsumowanie}

Reasumując zaprezentowane powyżej prace analityczne należy stwierdzić, iż w wyniku prowadzonych analiz zdefiniowano szereg nowych klasyfikacji terenów zieleni w mieście. Podjęte badania miały charakter porządkujący a ich celem było opracowanie nowego podziału miejskich obiektów architektury krajobrazu. Takiego, który oparty byłby na czytelnych podstawach, operującego jednoznacznie rozumianymi (nie pokrywającymi się) nazwami. Jednocześnie takiego, który sumuje dorobek wielu środowisk zajmujących się tą problematyką w przeszłości.

Wprowadzona systematyka obiektów architektury krajobrazu pozwala na odniesienie każdego z nich do zagadnień z zakresu planowania przestrzennego, określenia jego lokalizacji w mieście (w zdefiniowanej strefie 
funkcjonalna - przestrzennej), definiowanie go przy użyciu cech określonych w trzech klasyfikacjach prowadzonych ze względu na: dostępność terenu, jego funkcję użytkową oraz urządzenie i wyposażenie terenu ponadto przyporządkowanie mu stawianych zadań. Poniżej zaprezentowano ostateczne wyniki prowadzonych prac. Poszczególne obiekty usystematyzowano w porządku alfabetycznym.

alpinarium (ZP/Strefa II/2/1/3)

- charakterystyka obiektu: dostępność: ograniczona, funkcja użytkowa: rekreacyjno-wypoczynkowa, urządzenie i wyposażenie: tereny projektowane i realizowane kompleksowo;

nadania obiektu: biologiczne, zdrowotne, usługowe, psychiczne, wychowawcze, dydaktyczne, artystyczne;

arboretto (ZP/Strefa VI/2/1/2)

- charakterystyka obiektu: dostępność: ograniczona, funkcja użytkowa: rekreacyjno-wypoczynkowa, urządzenie i wyposażenie: tereny projektowane i realizowane kompleksowo;

- zadania obiektu: biologiczne, zdrowotne, usługowe, psychiczne, wychowawcze, dydaktyczne, artystyczne;

bazy sportów wodnych (ZS/ Strefa VI, VII /1/4/1)

- charakterystyka obiektu: dostępność: ograniczona, funkcja użytkowa: rekreacyjno-wypoczynkowa, urządzenie i wyposażenie: tereny projektowane i realizowane kompleksowo;

- zadania obiektu: biologiczne, zdrowotne, usługowe, społeczne, wychowawcze, artystyczne, estetyczne;

boiska terenowe (ZS/Strefa III, IV/1/2/1)

- charakterystyka obiektu: dostępność: ograniczona, funkcja użytkowa: rozdzielająca, rekreacyjno-wypoczynkowa, urządzenie i wyposażenie: tereny projektowane i realizowane kompleksowo;

nadania obiektu: biologiczne, zdrowotne, usługowe, społeczne, wychowawcze, artystyczne, estetyczne;

bulwar (ZP/Strefa II/3/2/4)

- charakterystyka obiektu: dostępność: pełna, funkcja użytkowa: rekreacyjno-wypoczynkowa, urządzenie i wyposażenie: tereny projektowane i realizowane kompleksowo;

- zadania obiektu: biologiczne, zdrowotne, usługowe, społeczne, psychiczne, wychowawcze, dydaktyczne, artystyczne, estetyczne, reprezentacyjne;

centrum handlowe (ZP/Strefa VIII/6/3/2)

- charakterystyka obiektu: dostępność: pełna, funkcja użytkowa: rekreacyjno-wypoczynkowa, towarzyszenie budynkom, urządzenie i wyposażenie: tereny projektowane i realizowane kompleksowo;

- zadania obiektu: biologiczne, zdrowotne, usługowe, społeczne, psychiczne, wychowawcze, artystyczne, estetyczne, reprezentacyjne;

cmentarz (ZC/Strefa VI/1/1/1)

- charakterystyka obiektu: dostępność: ograniczona, funkcja użytkowa: inna niesklasyfikowana, urządzenie i wyposażenie: tereny projektowane i realizowane kompleksowo;

- zadania obiektu: biologiczne, zdrowotne, społeczne, artystyczne, estetyczne;

dziedziniec międzyblokowy z placem zabaw dla dzieci małych (0-5 lat) i średnich (5-10 lat) i miejscem odpoczynku (ZP/Strefa II, III/4/1/3)

- charakterystyka obiektu: dostępność: penła lub regulowana przez właściciela, funkcja użytkowa: rekreacyjno-wypoczynkowa, urządzenie i wyposażenie: tereny powstające przy współudziale społecznym lub w wyniku samowoli inwestycyjnej;

- zadania obiektu: biologiczne, zdrowotne, usługowe, społeczne, psychiczne, wychowawcze, artystyczne, estetyczne; 
fortyfikacje (ZP/Strefa II/1/2/2)

- charakterystyka obiektu: dostępność: ograniczona, funkcja użytkowa: rekreacyjno-wypoczynkowa, urządzenie i wyposażenie: tereny projektowane i realizowane kompleksowo;

- zadania obiektu: biologiczne, zdrowotne, usługowe, psychiczne, wychowawcze, dydaktyczne, artystyczne, estetyczne, reprezentacyjne;

gospodarstwa rolne (wydzielone) (ZR/Strefa VI/1/1/1)

- charakterystyka obiektu: dostępność: brak, funkcja użytkowa: produkcja rolnicza, urządzenie i wyposażenie: tereny projektowane i realizowane kompleksowo;

- zadania obiektu: biologiczne, zdrowotne, artystyczne, gospodarcze, ochronne;

grodzisko (ZP/Strefa IV/1/2/1)

- charakterystyka obiektu: dostępność: pełna lub ograniczona, funkcja użytkowa: rekreacyjno-wypoczynkowa, urządzenie i wyposażenie: tereny projektowane i realizowane kompleksowo;

zadania obiektu: biologiczne, zdrowotne, usługowe, psychiczne, wychowawcze, dydaktyczne, artystyczne, estetyczne, reprezentacyjne;

kampus uczelni wyższej (ZP/Strefa VIII/5/1/1)

- charakterystyka obiektu: dostępność: ograniczona, funkcja użytkowa: rekreacyjno-wypoczynkowa, towarzyszenie budynkom, urządzenie i wyposażenie: tereny projektowane i realizowane kompleksowo;

- zadania obiektu: biologiczne, zdrowotne, usługowe, społeczne, estetyczne, reprezentacyjne;

las komunalny (ZL/Strefa VI/1/1/1)

- charakterystyka obiektu: dostępność: pełna, funkcja użytkowa: rozdzielająca, rekreacyjno-wypoczynkowa, urządzenie i wyposażenie: tereny pozostawione bez zagospodarowania;

- zadania obiektu: biologiczne, zdrowotne, usługowe, wychowawcze, dydaktyczne, artystyczne, ochronne, przeciwpożarowe;

łąki i błonia (ZB/Strefa VI/1/1/1)

- charakterystyka obiektu: dostępność: pełna, funkcja użytkowa: rekreacyjno-wypoczynkowa, urządzenie i wyposażenie: tereny pozostawione bez zagospodarowania;

- zadania obiektu: biologiczne, zdrowotne, usługowe, artystyczne, przeciwpożarowe;

miasteczko ruchu drogowego (ZP/Strefa IV, VI/2/2/5)

- charakterystyka obiektu: dostępność: pełna lub ograniczona, funkcja użytkowa: rozdzielająca, rekreacyjno-wypoczynkowa, urządzenie i wyposażenie: tereny projektowane i realizowane kompleksowo;

- zadania obiektu: biologiczne, zdrowotne, usługowe, psychiczne, wychowawcze, dydaktyczne, artystyczne;

miejsca odpoczynku osób starszych (ZP/Strefa II, III, VI /4/2/7)

- charakterystyka obiektu: dostępność: pełna, funkcja użytkowa: rekreacyjno-wypoczynkowa, urządzenie i wyposażenie: tereny powstające przy współudziale społecznym;

nadania obiektu: biologiczne, zdrowotne, usługowe, społeczne, psychiczne, wychowawcze, artystyczne, estetyczne;

nieużytki (ZB/Strefa VI/1/1/2)

- charakterystyka obiektu: dostępność: pełna, funkcja użytkowa: inna niesklasyfikowana, urządzenie i wyposażenie: tereny pozostawione bez zagospodarowania;

nadania obiektu: biologiczne, zdrowotne, usługowe, artystyczne, przeciwpożarowe;

ogrody działkowe (ZD/Strefa IV, VI/1/1/1)

- charakterystyka obiektu: dostępność: brak, funkcja użytkowa: rozdzielająca, rekreacyjno-wypoczynkowa, produkcja rolnicza, urządzenie i wyposażenie: tereny powstające przy współudziale społecznym; 
- zadania obiektu: biologiczne, zdrowotne, usługowe, społeczne, psychiczne, wychowawcze, dydaktyczne, artystyczne, gospodarcze, ochronne, przeciwpożarowe;

ogród botaniczny (ZP/Strefa II, VI/2/1/1)

- charakterystyka obiektu: dostępność: ograniczona, funkcja użytkowa: rekreacyjno-wypoczynkowa, urządzenie i wyposażenie: tereny projektowane i realizowane kompleksowo;

- zadania obiektu: biologiczne, zdrowotne, usługowe, psychiczne, wychowawcze, dydaktyczne, artystyczne;

ogród dydaktyczny (ZP/Strefa IV/2/2/3)

n charakterystyka obiektu: dostępność: ograniczona, funkcja użytkowa: rozdzielająca, rekreacyjno-wypoczynkowa, urządzenie i wyposażenie: tereny projektowane i realizowane kompleksowo;

- zadania obiektu: biologiczne, zdrowotne, usługowe, psychiczne, wychowawcze, dydaktyczne, artystyczne;

ogród etnograficzny (ZP/Strefa VI/2/2/2)

- charakterystyka obiektu: dostępność: ograniczona, funkcja użytkowa: rekreacyjno-wypoczynkowa, urządzenie i wyposażenie: tereny projektowane i realizowane kompleksowo;

- zadania obiektu: biologiczne, zdrowotne, usługowe, psychiczne, wychowawcze, dydaktyczne, artystyczne;

ogród osiedlowy (ZP/Strefa III/4/1/2)

- charakterystyka obiektu: dostępność: pełna, funkcja użytkowa: rekreacyjno-wypoczynkowa, urządzenie i wyposażenie: tereny powstające przy współudziale społecznym;

- zadania obiektu: biologiczne, zdrowotne, usługowe, społeczne, psychiczne, wychowawcze, artystyczne, estetyczne;

ogród przy hospicjum (ZP/Strefa IV/7/1/2)

- charakterystyka obiektu: dostępność: brak, funkcja użytkowa: rekreacyjno-wypoczynkowa, towarzyszenie budynkom, urządzenie i wyposażenie: tereny projektowane i realizowane kompleksowo;

- zadania obiektu: biologiczne, zdrowotne, usługowe, społeczne, psychiczne, wychowawcze, dydaktyczne, artystyczne, estetyczne;

ogród przy szpitalu (ZP/Strefa IV/7/1/1)

- charakterystyka obiektu: dostępność: brak, funkcja użytkowa: rekreacyjno-wypoczynkowa, towarzyszenie budynkom, urządzenie i wyposażenie: tereny projektowane i realizowane kompleksowo;

- zadania obiektu: biologiczne, zdrowotne, usługowe, społeczne, psychiczne, wychowawcze, dydaktyczne, artystyczne, estetyczne;

ogród zabytkowy (ZP/Strefa II/1/1/2)

- charakterystyka obiektu: dostępność: ograniczona, funkcja użytkowa: rekreacyjno-wypoczynkowa, urządzenie i wyposażenie: tereny projektowane i realizowane kompleksowo;

- zadania obiektu: biologiczne, zdrowotne, usługowe, psychiczne, wychowawcze, dydaktyczne, artystyczne, estetyczne, reprezentacyjne;

ogród zoologiczny (ZP/Strefa II, VI/2/2/1)

- charakterystyka obiektu: dostępność: ograniczona, funkcja użytkowa: rekreacyjno-wypoczynkowa, urządzenie i wyposażenie: tereny projektowane i realizowane kompleksowo;

- zadania obiektu: biologiczne, zdrowotne, usługowe, psychiczne, wychowawcze, dydaktyczne, artystyczne;

ogródek indywidualny dostępny z mieszkania na I kondygnacji (ZP/Strefa III/4/1/4)

- charakterystyka obiektu: dostępność: brak, funkcja użytkowa: rekreacyjno-wypoczynkowa, urządzenie i wyposażenie: tereny powstające przy współudziale społecznym lub w wyniku samowoli inwestycyjnej;

- zadania obiektu: biologiczne, zdrowotne, usługowe, społeczne, psychiczne, wychowawcze, artystyczne, estetyczne; 
osiedlowe centrum handlowo-usługowe, galeria handlowa (ZP/Strefa II, III/6/3/1)

- charakterystyka obiektu: dostępność: pełna, funkcja użytkowa: rekreacyjno-wypoczynkowa, towarzyszenie budynkom, urządzenie i wyposażenie: tereny projektowane i realizowane kompleksowo;

- zadania obiektu: biologiczne, zdrowotne, usługowe, społeczne, psychiczne, wychowawcze, artystyczne, estetyczne, reprezentacyjne;

otoczenie hal sportowych (w tym: kortów tenisowych, lodowisk, basenów, itp.) (ZS/Strefa VIII/1/1/2)

- charakterystyka obiektu: dostępność: ograniczona, funkcja użytkowa: rekreacyjno-wypoczynkowa, towarzyszenie budynkom, urządzenie i wyposażenie: tereny projektowane i realizowane kompleksowo;

- zadania obiektu: biologiczne, zdrowotne, usługowe, społeczne, wychowawcze, artystyczne, estetyczne;

otoczenie hotelu (ZP/Strefa VIII/6/4/1)

- charakterystyka obiektu: dostępność: brak, funkcja użytkowa: rekreacyjno-wypoczynkowa, towarzyszenie budynkom, urządzenie i wyposażenie: tereny projektowane i realizowane kompleksowo;

zadania obiektu: biologiczne, zdrowotne, usługowe, społeczne, psychiczne, wychowawcze, artystyczne, estetyczne, reprezentacyjne;

otoczenie obiektu biurowego (ZP/ Strefa VIII/6/4/1)

- charakterystyka obiektu: dostępność: pełna, funkcja użytkowa: rekreacyjno-wypoczynkowa, towarzyszenie budynkom, urządzenie i wyposażenie: tereny projektowane i realizowane kompleksowo;

- zadania obiektu: biologiczne, zdrowotne, usługowe, społeczne, psychiczne, wychowawcze, artystyczne, estetyczne, reprezentacyjne;

otoczenie stadionów (ZS/Strefa VI/1/1/1)

- charakterystyka obiektu: dostępność: brak, funkcja użytkowa: rekreacyjno-wypoczynkowa, towarzyszenie budynkom, urządzenie i wyposażenie: tereny projektowane i realizowane kompleksowo;

- zadania obiektu: biologiczne, zdrowotne, usługowe, społeczne, wychowawcze, artystyczne, estetyczne;

park centralny (ZP/Strefa II, IV/3/1/3)

- charakterystyka obiektu: dostępność: pełna, funkcja użytkowa: rekreacyjno-wypoczynkowa, urządzenie i wyposażenie: tereny projektowane i realizowane kompleksowo;

- zadania obiektu: biologiczne, zdrowotne, usługowe, społeczne, psychiczne, wychowawcze, dydaktyczne, artystyczne, estetyczne, reprezentacyjne;

park dzielnicowy (ZP/Strefa IV/3/1/4)

- charakterystyka obiektu: dostępność: pełna, funkcja użytkowa: rozdzielająca, rekreacyjno-wypoczynkowa, urządzenie i wyposażenie: tereny powstające przy współudziale społecznym;

- zadania obiektu: biologiczne, zdrowotne, usługowe, społeczne, psychiczne, wychowawcze, dydaktyczne, artystyczne, estetyczne, reprezentacyjne;

park integracji (ZP/Strefa II, IV, VI/2/2/4)

- charakterystyka obiektu: dostępność: ograniczona, funkcja użytkowa: rozdzielająca, rekreacyjno-wypoczynkowa, urządzenie i wyposażenie: tereny projektowane i realizowane kompleksowo;

- zadania obiektu: biologiczne, zdrowotne, usługowe, psychiczne, wychowawcze, dydaktyczne, artystyczne;

park kultury i wypoczynku (park ludowy) (ZP/Strefa IV, VI/3/1/1)

- charakterystyka obiektu: dostępność: pełna, funkcja użytkowa: rozdzielająca, rekreacyjno-wypoczynkowa, urządzenie i wyposażenie: tereny projektowane i realizowane kompleksowo;

- zadania obiektu: biologiczne, zdrowotne, usługowe, społeczne, psychiczne, wychowawcze, dydaktyczne, artystyczne, estetyczne, reprezentacyjne; 
park miejski (ZP/Strefa II/3/1/2)

- charakterystyka obiektu: dostępność: pełna, funkcja użytkowa: rekreacyjno-wypoczynkowa, urządzenie i wyposażenie: tereny projektowane i realizowane kompleksowo;

- zadania obiektu: biologiczne, zdrowotne, usługowe, społeczne, psychiczne, wychowawcze, dydaktyczne, artystyczne, estetyczne, reprezentacyjne;

park osiedlowy (ZP/Strefa III/4/1/1)

- charakterystyka obiektu: dostępność: pełna, funkcja użytkowa: rekreacyjno-wypoczynkowa, urządzenie i wyposażenie: tereny powstające przy współudziale społecznym;

nadania obiektu: biologiczne, zdrowotne, usługowe, społeczne, psychiczne, wychowawcze, artystyczne, estetyczne;

park zabytkowy (ZP/Strefa II/1/1/1)

- charakterystyka obiektu: dostępność: ograniczona, funkcja użytkowa: rekreacyjno-wypoczynkowa, urządzenie i wyposażenie: tereny projektowane i realizowane kompleksowo;

- zadania obiektu: biologiczne, zdrowotne, usługowe, psychiczne, wychowawcze, dydaktyczne, artystyczne, estetyczne, reprezentacyjne;

pasaż (ZP/Strefa I, II/3/3/2)

n charakterystyka obiektu: dostępność: pełna, funkcja użytkowa: rekreacyjno-wypoczynkowa, urządzenie i wyposażenie: tereny projektowane i realizowane kompleksowo;

nadania obiektu: biologiczne, zdrowotne, usługowe, społeczne, psychiczne, wychowawcze, dydaktyczne, artystyczne, estetyczne, reprezentacyjne;

plac miejski (ZP/Strefa I, II/3/3/1)

n charakterystyka obiektu: dostępność: pełna, funkcja użytkowa: rekreacyjno-wypoczynkowa, urządzenie i wyposażenie: tereny projektowane i realizowane kompleksowo;

nadania obiektu: biologiczne, zdrowotne, usługowe, społeczne, psychiczne, wychowawcze, dydaktyczne, artystyczne, estetyczne, reprezentacyjne;

plac zabaw dla dzieci małych (0-5 lat) (ZP/Strefa III/4/2/1)

- charakterystyka obiektu: dostępność: pełna, funkcja użytkowa: rekreacyjno-wypoczynkowa, urządzenie i wyposażenie: tereny powstające przy współudziale społecznym;

- zadania obiektu: biologiczne, zdrowotne, usługowe, społeczne, psychiczne, wychowawcze, artystyczne, estetyczne;

plac zabaw dla dzieci starszych (10-15 lat) (ZP/Strefa II, III, VI /4/2/3)

- charakterystyka obiektu: dostępność: pełna, funkcja użytkowa: rekreacyjno-wypoczynkowa, urządzenie i wyposażenie: tereny powstające przy współudziale społecznym;

- zadania obiektu: biologiczne, zdrowotne, usługowe, społeczne, psychiczne, wychowawcze, artystyczne, estetyczne;

plac zabaw dla dzieci średnich (5-10 lat) (ZP/Strefa II, III, VI/4/2/2)

n charakterystyka obiektu: dostępność: pełna, funkcja użytkowa: rekreacyjno-wypoczynkowa, urządzenie i wyposażenie: tereny powstające przy współudziale społecznym;

- zadania obiektu: biologiczne, zdrowotne, usługowe, społeczne, psychiczne, wychowawcze, artystyczne, estetyczne;

plaża (kąpielisko) (ZS/Strefa VI, VII/1/3/1)

- charakterystyka obiektu: dostępność: ograniczona, funkcja użytkowa: rekreacyjno-wypoczynkowa, urządzenie i wyposażenie: tereny projektowane i realizowane kompleksowo;

- zadania obiektu: biologiczne, zdrowotne, usługowe, społeczne, wychowawcze, artystyczne, estetyczne; 
pola golfowe (ZS/Strefa VI/1/2/2)

- charakterystyka obiektu: dostępność: ograniczona, funkcja użytkowa: rekreacyjno-wypoczynkowa, urządzenie i wyposażenie: tereny projektowane i realizowane kompleksowo;

- zadania obiektu: biologiczne, zdrowotne, usługowe, społeczne, wychowawcze, artystyczne, estetyczne;

produkcja rolnicza na terenie otwartym (ZR/Strefa VI/1/1/2)

- charakterystyka obiektu: dostępność: pełna lub brak, funkcja użytkowa: produkcja rolnicza, urządzenie i wyposażenie: tereny projektowane i realizowane kompleksowo;

- zadania obiektu: biologiczne, zdrowotne, wychowawcze, dydaktyczne, artystyczne, ochronne;

promenada (ZP/Strefa II/3/2/3)

- charakterystyka obiektu: dostępność: pełna, funkcja użytkowa: rekreacyjno-wypoczynkowa, urządzenie i wyposażenie: tereny projektowane i realizowane kompleksowo;

- zadania obiektu: biologiczne, zdrowotne, usługowe, społeczne, psychiczne, wychowawcze, dydaktyczne, artystyczne, estetyczne, reprezentacyjne;

rezerwat przyrody (ZN/Strefa VI, VII/1/1/1)

n charakterystyka obiektu: dostępność: pełna, funkcja użytkowa: rozdzielająca, rekreacyjno-wypoczynkowa, urządzenie i wyposażenie: tereny pozostawione bez zagospodarowania;

nadania obiektu: biologiczne, zdrowotne, usługowe, wychowawcze, dydaktyczne, artystyczne, ochronne;

siłownia na wolnym powietrzu (ZP/Strefa III, VI /4/2/5)

- charakterystyka obiektu: dostępność: pełna, funkcja użytkowa: rekreacyjno-wypoczynkowa, urządzenie i wyposażenie: tereny powstające przy współudziale społecznym;

- zadania obiektu: biologiczne, zdrowotne, usługowe, społeczne, psychiczne, wychowawcze, artystyczne, estetyczne;

skatepark (ZS/Strefa III, IV/1/2/3)

- charakterystyka obiektu: dostępność: ograniczona, funkcja użytkowa: rozdzielająca, rekreacyjno-wypoczynkowa, urządzenie i wyposażenie: tereny projektowane i realizowane kompleksowo;

- zadania obiektu: biologiczne, zdrowotne, usługowe, społeczne, wychowawcze, artystyczne, estetyczne;

skwer (ZP/Strefa I, II/3/2/2)

- charakterystyka obiektu: dostępność: pełna lub ograniczona, funkcja użytkowa: rekreacyjno-wypoczynkowa, urządzenie i wyposażenie: tereny projektowane i realizowane kompleksowo;

- zadania obiektu: biologiczne, zdrowotne, usługowe, społeczne, psychiczne, wychowawcze, dydaktyczne, artystyczne, estetyczne, reprezentacyjne;

stok narciarski (ZS/Strefa $\mathrm{VI} / 1 / 5 / 1)$

- charakterystyka obiektu: dostępność: ograniczona, funkcja użytkowa: rekreacyjno-wypoczynkowa, urządzenie i wyposażenie: tereny projektowane i realizowane kompleksowo;

- zadania obiektu: biologiczne, zdrowotne, usługowe, społeczne, wychowawcze, artystyczne, estetyczne;

ścieżka zdrowia (ZP/Strefa III, VI, VI /4/2/6)

- charakterystyka obiektu: dostępność: pełna, funkcja użytkowa: rekreacyjno-wypoczynkowa, urządzenie i wyposażenie: tereny powstające przy współudziale społecznym;

- zadania obiektu: biologiczne, zdrowotne, usługowe, społeczne, psychiczne, wychowawcze, artystyczne, estetyczne;

teren działki: amfiteatru (ZP/Strefa I, II, III, IV, VI/6/2/2)

- charakterystyka obiektu: dostępność: pełna, funkcja użytkowa: rekreacyjno-wypoczynkowa, towarzyszenie budynkom, urządzenie i wyposażenie: tereny projektowane i realizowane kompleksowo; 
- zadania obiektu: biologiczne, zdrowotne, usługowe, społeczne, psychiczne, wychowawcze, artystyczne, estetyczne, reprezentacyjne;

teren działki kościoła (innego obiektu sakralnego) (ZP/Strefa I, II, III/6/1/1)

- charakterystyka obiektu: dostępność: ograniczona, funkcja użytkowa: rekreacyjno-wypoczynkowa, towarzyszenie budynkom, urządzenie i wyposażenie: tereny powstające przy współudziale społecznym;

- zadania obiektu: biologiczne, zdrowotne, usługowe, społeczne, psychiczne, wychowawcze, artystyczne, estetyczne, reprezentacyjne;

teren działki obiektu ochrony zdrowia (przychodni) (ZP/Strefa III/7/2/1)

- charakterystyka obiektu: dostępność: pełna, funkcja użytkowa: rekreacyjno-wypoczynkowa, towarzyszenie budynkom, urządzenie i wyposażenie: tereny projektowane i realizowane kompleksowo;

- zadania obiektu: biologiczne, zdrowotne, usługowe, społeczne, psychiczne, wychowawcze, dydaktyczne, artystyczne, estetyczne;

teren działki obiektu z mieszkaniami dla osób starszych i niepełnosprawnych (ZP/Strefa III/7/2/2)

- charakterystyka obiektu: dostępność: pełna, funkcja użytkowa: rekreacyjno-wypoczynkowa, urządzenie i wyposażenie: tereny projektowane i realizowane kompleksowo;

- zadania obiektu: biologiczne, zdrowotne, usługowe, społeczne, psychiczne, wychowawcze, dydaktyczne, artystyczne, estetyczne;

teren działki przedszkola (ZP/Strefa II, III /5/2/2)

- charakterystyka obiektu: dostępność: wejście kontrolowane, funkcja użytkowa: rekreacyjno-wypoczynkowa, towarzyszenie budynkom, urządzenie i wyposażenie: tereny projektowane i realizowane kompleksowo;

- zadania obiektu: biologiczne, zdrowotne, usługowe, społeczne, wychowawcze, dydaktyczne, artystyczne, estetyczne, reprezentacyjne;

teren działki szkoły podstawowej (ZP/Strefa II, III /5/2/3)

- charakterystyka obiektu: dostępność: wejście kontrolowane, funkcja użytkowa: rekreacyjno-wypoczynkowa, towarzyszenie budynkom, urządzenie i wyposażenie: tereny projektowane i realizowane kompleksowo;

- zadania obiektu: biologiczne, zdrowotne, usługowe, społeczne, wychowawcze, dydaktyczne, artystyczne, estetyczne, reprezentacyjne;

teren działki szkoły ponadpodstawowej (ZP/Strefa II, III /5/2/4)

- charakterystyka obiektu: dostępność: ograniczona, funkcja użytkowa: rekreacyjno-wypoczynkowa, towarzyszenie budynkom, urządzenie i wyposażenie: tereny projektowane i realizowane kompleksowo;

- zadania obiektu: biologiczne, zdrowotne, usługowe, społeczne, wychowawcze, dydaktyczne, artystyczne, estetyczne, reprezentacyjne;

teren działki żłobka (ZP/Strefa II, III/5/2/1)

- charakterystyka obiektu: dostępność: wejście kontrolowane, funkcja użytkowa: rekreacyjno-wypoczynkowa, towarzyszenie budynkom, urządzenie i wyposażenie: tereny projektowane i realizowane kompleksowo;

- zadania obiektu: biologiczne, zdrowotne, usługowe, społeczne, wychowawcze, dydaktyczne, artystyczne, estetyczne, reprezentacyjne;

teren działki: muzeum, teatru, itp. (ZP/Strefa I, II/6/2/1)

- charakterystyka obiektu: dostępność: pełna, funkcja użytkowa: rekreacyjno-wypoczynkowa, towarzyszenie budynkom, urządzenie i wyposażenie: tereny projektowane i realizowane kompleksowo;

- zadania obiektu: biologiczne, zdrowotne, usługowe, społeczne, psychiczne, wychowawcze, artystyczne, estetyczne, reprezentacyjne; 
tereny gier i zabaw dla młodzieży i dorosłych (ZP/Strefa III, VI /4/2/4)

- charakterystyka obiektu: dostępność: pełna, funkcja użytkowa: rekreacyjno-wypoczynkowa, urządzenie i wyposażenie: tereny powstające przy współudziale społecznym;

- zadania obiektu: biologiczne, zdrowotne, usługowe, społeczne, psychiczne, wychowawcze, artystyczne, estetyczne;

tereny rozdzielające osiedla i dzielnice mieszkaniowe (ZP/Strefa IV/9/2/1)

- charakterystyka obiektu: dostępność: pełna, funkcja użytkowa: rekreacyjno-wypoczynkowa, urządzenie i wyposażenie: tereny powstające przy współudziale społecznym lub pozostawione bez zagospodarowania;

- zadania obiektu: biologiczne, zdrowotne, artystyczne, ochronne, przeciwpożarowe;

tereny zalewowe o różnym sposobie użytkowania (ZZ/Strefa VI/1/1/1)

- charakterystyka obiektu: dostępność: pełna, funkcja użytkowa: rekreacyjno-wypoczynkowa, produkcja rolnicza, urządzenie i wyposażenie: tereny pozostawione bez zagospodarowania;

- zadania obiektu: biologiczne, zdrowotne, usługowe, artystyczne, ochronne, przeciwpożarowe;

tory samochodowe (ZS/Strefa III, IV/1/2/4)

- charakterystyka obiektu: dostępność: ograniczona, funkcja użytkowa: rozdzielająca, rekreacyjno-wypoczynkowa, urządzenie i wyposażenie: tereny projektowane i realizowane kompleksowo;

- zadania obiektu: biologiczne, zdrowotne, usługowe, społeczne, wychowawcze, artystyczne, estetyczne;

trasy do jazdy konnej (ZS/Strefa VI, VII/1/5/4)

- charakterystyka obiektu: dostępność: pełna, funkcja użytkowa: rekreacyjno-wypoczynkowa, urządzenie i wyposażenie: tereny projektowane i realizowane kompleksowo;

zadania obiektu: biologiczne, zdrowotne, usługowe, społeczne, wychowawcze, artystyczne, estetyczne;

trasy kolarskie (ZS/Strefa VI, VII/1/5/2)

- charakterystyka obiektu: dostępność: pełna, funkcja użytkowa: rekreacyjno-wypoczynkowa, urządzenie i wyposażenie: tereny projektowane i realizowane kompleksowo;

- zadania obiektu: biologiczne, zdrowotne, usługowe, społeczne, wychowawcze, artystyczne, estetyczne;

trasy lekkoatletyczne (ZS/Strefa VI, VII/1/5/1)

- charakterystyka obiektu: dostępność: pełna, funkcja użytkowa: rekreacyjno-wypoczynkowa, urządzenie i wyposażenie: tereny projektowane i realizowane kompleksowo;

- zadania obiektu: biologiczne, zdrowotne, usługowe, społeczne, wychowawcze, artystyczne, estetyczne;

trasy kolarskie (ZS/Strefa VI, VII/1/5/3)

- charakterystyka obiektu: dostępność: pełna, funkcja użytkowa: rekreacyjno-wypoczynkowa, urządzenie i wyposażenie: tereny projektowane i realizowane kompleksowo;

- zadania obiektu: biologiczne, zdrowotne, usługowe, społeczne, wychowawcze, artystyczne, estetyczne;

wesołe miasteczko (ZP/Strefa IV, VI/2/2/6)

- charakterystyka obiektu: dostępność: pełna lub ograniczona, funkcja użytkowa: rozdzielająca, rekreacyjno-wypoczynkowa, urządzenie i wyposażenie: tereny projektowane i realizowane kompleksowo;

- zadania obiektu: biologiczne, zdrowotne, usługowe, psychiczne, wychowawcze, dydaktyczne, artystyczne;

wybieg dla psów (ZP/Strefa III, IV/4/2/8)

- charakterystyka obiektu: dostępność: pełna, funkcja użytkowa: rozdzielająca, rekreacyjno-wypoczynkowa, urządzenie i wyposażenie: tereny powstające przy współudziale społecznym;

- zadania obiektu: biologiczne, zdrowotne, usługowe, społeczne, psychiczne, wychowawcze, artystyczne, estetyczne; 
zieleniec (ZP/Strefa III/3/2/1)

- charakterystyka obiektu: dostępność: pełna, funkcja użytkowa: izolacyjna, urządzenie i wyposażenie: tereny projektowane i realizowane kompleksowo;

- zadania obiektu: biologiczne, zdrowotne, usługowe, społeczne, psychiczne, wychowawcze, dydaktyczne, artystyczne;

zieleń izolująca ciągi komunikacyjne (ZP/Strefa II, III/9/1/1)

- dostępność: pełna, funkcja użytkowa: izolacyjna, urządzenie i wyposażenie: tereny projektowane i realizowane kompleksowo;

- zadania obiektu: biologiczne, zdrowotne, artystyczne, ochronne, przeciwpożarowe;

zieleń izolująca zakłady przemysłowe (ZPR/Strefa V/1/1/1)

- charakterystyka obiektu: dostępność: pełna, funkcja użytkowa: izolacyjna, urządzenie i wyposażenie: tereny projektowane i realizowane kompleksowo lub pozostawione bez zagospodarowania;

- zadania obiektu: biologiczne, zdrowotne, artystyczne, ochronne, przeciwpożarowe;

zieleń przyuliczna (ZP/Strefa II, III/8/1/1)

- charakterystyka obiektu: dostępność: pełna, funkcja użytkowa: izolacyjna, urządzenie i wyposażenie: tereny projektowane i realizowane kompleksowo;

nadania obiektu: biologiczne, zdrowotne, artystyczne, estetyczne, ochronne;

zielone torowiska (ZP/Strefa II, III/8/2/1)

- charakterystyka obiektu: dostępność: pełna, funkcja użytkowa: izolacyjna, urządzenie i wyposażenie: tereny projektowane i realizowane kompleksowo;

- zadania obiektu: biologiczne, zdrowotne, artystyczne, estetyczne, ochronne;

\section{Classifications and tasks of green areas in the contemporary town}

Summary: The second part of research on the classification of green areas in the city is devoted to defining the features and tasks of distinguished landscape architecture objects. The characteristics of individual objects have been defined by the division into the issues of: the availability of the site, its utility function and, the way it's been equipped. The tasks have been determined on the basis of the modern theory of this subject. The conclusion shows the summary results of research.

Keywords: landscape architecture, area planning, green areas, town green zones, objects of landscape architecture 